\title{
Klima Atık Sularının Buğday ve Arpa Üzerindeki Etkilerinin Araştırılması
}

\author{
Müjgan ELVEREN*1, Tuğçe VAROL ${ }^{2}$, Etem OSMA ${ }^{2}$
}

\author{
Erzincan Binali Yıldırım Üniversitesi, Fen Bilimleri Enstitüsü, Erzincan, Türkiye \\ Erzincan Binali Yıldırım Üniversitesi, Fen Edebiyat Fakültesi, Biyoloji Bölümü, Erzincan, \\ Türkiye
}

Geliş / Received: 20/03/2018, Kabul / Accepted: 13/09/2018

\begin{abstract}
Öz
$\mathrm{Bu}$ çalışma ile günümüzde her geçen gün kullanımı artan klimalardan, ekosisteme bulaşabilecek atık suların arpa (Hordeum vulgare L.) ve buğday (Triticum aestivum L.) bitkileri üzerindeki etkisi araştırılmıştır. Çalışma için ekim yapılacak toprağa, kontrol grubunun haricinde sulamada kullanılan suya farklı konsantrasyonlarda $(1 / 5,2 / 5,3 / 5)$ klima atık suları karıştırılmıştır. $650 \mathrm{~g}$ toprağın üzerine $5 \mathrm{~g}$ arpa ve $7 \mathrm{~g}$ buğday tohumu ekilmiş, bunun üzeri ise $100 \mathrm{~g}$ toprak ile örtülmüştür. Tarla kapasitesine uygun olarak buğdaylar belirli aralıklarla sulanmıştır. Buğdaylar, 15 gün, arpalar ise 11 günün sonunda hasat edilmiştir. Hasat edilen örneklerin ağırlıkları ölçüldükten sonra, ekstraksiyon işlemi uygulanarak örneklerde elektrolit sızıntı, MDA, CAT, SOD aktiviteleri belirlenmiştir. Bununla birlikte buğday ve arpa örnekleri, ön işlemlerden geçirildikten sonra metal konsantrasyonları ICP-OES cihazında analiz edilmiştir. Kontrol örnekleri ile klima atık sularının farklı konsantrasyonlarında yetiştirilen örnekler arasındaki ilişki istatistiksel olarak değerlendirilmiş, anlamlı farklılıklar tespit edilmiştir.
\end{abstract}

Anahtar Kelimeler: Arpa, Buğday, Klima Atık Suyu, ICP-OES, MDA, SOD

\section{Investigation of the Effects of Air Conditioner Waste Water on Wheat and Barley}

\begin{abstract}
Herein this study, the effects of the wastewaters that transmitted to the ecosystem from the air conditioner on the barley (Hordeum vulgare L.) and wheat (Triticum aestivum L.) plants were investigated. The soil to be planted for study was mixed at different concentrations $(1 / 5,2 / 5,3 / 5)$ of the air conditioner wastewater except for the control group. On $650 \mathrm{~g}$ of soil $5 \mathrm{~g}$ of barley and $7 \mathrm{~g}$ of wheat seed were planted and covered with $100 \mathrm{~g}$ of soil. Wheat was irrigated at regular intervals in accordance with field capacity. The wheat was harvested after 15 days and the barley was harvested after 11 days. After weighing the harvested samples electrolyte leakage, MDA, CAT, SOD activities were determined by extraction. Along with that wheat and barley specimens were analyzed for metal concentrations in ICP-OES after pre-treatment. The relationship between control samples and samples grown at different concentrations of $\mathrm{A} / \mathrm{C}$ wastewater was evaluated statistically and significant differences were determined.
\end{abstract}

Keywords: Barley, Wheat, Conditioner Waste Water, ICP-OES, MDA, SOD

\section{Giriş}

Nüfusun hızla artışı ve teknolojik gelişmeler, üretimin artmasına ve kaynakların daha çok kullanılmasına neden olmuştur. İnsanoğlu ihtiyaçları doğrultusunda doğal kaynakları bilinçsiz şekilde kullanarak, ekosisteme ciddi zararlar vermektedir. Ekonomik, teknolojik, sosyal vb. alanlardaki ilerlemeler çevresel değerlerin yok olmasına zemin hazırlamaya başlamıştır (Tıraş, 2012). Sanayi ve teknolojinin gelişimi ile birlikte çevre sorunları giderek artmaktadır. Yine kentleşme ile beraber, bölgesel kuraklık ve kirlilik ciddi oranda artış göstermeye başlamıştır. Son yıllarda yapılan çalışmalara göre, toksik inorganik kirleticiler, organik kirleticiler, sanayi atıkları ve patojenler arıtılmamış sulara karışabilir ve bu kirleticiler genellikle biyolojik olarak aktif özelliğe sahip olup, ekosistemde önemli riskler oluşturabilmektedir (Chen vd., 2011; 
Yan vd., 2013; Pan ve Chu, 2017). İnsan nüfusu sürekli artmaktadır. Dünya çapındaki insan nüfusunun yarisindan fazlası bugünlerde şehirlerde yaşamaktadır ve bu şekilde devam ettiğinde önümüzdeki 25 yıl içinde hızla artması beklenmektedir (Stagoll vd., 2010; Duenas vd., 2014). Bununla birlikte, şehirler sağlıklı çevreleri temsil etmekten çok uzakta olup, nüfus artışı, su, elektrik, karayolları, telekomünikasyon vb. hizmetlerin artışı çevre problemlerini artırmaktadır. Dolayısıyla, kentsel ekosistemler kentleşme ve endüstriyel süreçlerin bir sonucu olarak ciddi oranda kirlenmektedir (Albayrak ve Mor, 2011; Duenas vd., 2014). Yaşam alanlarında konfor isteği iklimlendirme ihtiyacını artırmıştır. Dünyada iklim değişikliği ve küresel ısınmanın oluşturduğu aşırı sıcakların etkisine bağlı olarak klima sektörü önemli bir pazar haline gelmiştir. Dünyada tüketilen enerji potansiyelinin yaklaşık \% 9'u iklimlendirme ve soğutma sektöründe iken, klima sektörü yaklaşık \% 28'lik bir paya ulaşmıştır. Günümüzde yaklaşık olarak yıllık 60-70 milyon soğutma sistemi üretilmektedir bununla birlikte çeşitli uygulamalarda yüz milyonlarca soğutucu ve iklimlendirme ünitesi çalışmaktadır. Hem ülkemizde hem de dünyada sıcaklıkların artışına bağlı olarak klima satışları gittikçe artmaktadır (Söğüt ve Karakoç, 2013). Kapalı alan kirliliği şuan itibariyle önemli halk sağlığ1 problemlerinden bir tanesidir. Çünkü insanlar günün yaklaşı \% 80'inden fazlasını iç mekanlarda harcamaktadır ve kapalı ortamlarda mevcut olan çeşitli kirleticiler insan sağlığına zararlı olabilmektedir (Righi vd., 2002; Özçimen vd., 2012). Genel olarak, klimalı binalarda iç hava kalitesi klima sistemlerinin düzgün kullanılmaması, mikroorganizmaların çoğalması için uygun şartlar oluşturmaktadır (Özçimen vd., 2012). Sicaklık, nem, hava değişimi, hava hareketi, havalandırma, parçacık kirleticileri, biyolojik kirleticiler ve gaz kirletici maddeler, kapalı hava kirliliğinin kaynakları arasında yer almaktadır (Graudenz vd., 2005; Özçimen vd., 2012). Dolaysıyla klimaya bağlı birçok hastalı ortaya çıkabilmektedir. Bunun haricinde klimaların çalışma süreçleri içerisinde ortaya çıkan atık suların hakkında çok fazla bilgi bulunmamaktadır. Şehirlerde birçok klimanın kullanımıyla birlikte oluşan atık suların ekosistem üzerindeki etkileri bugüne kadar çok fazla araştırılmamıştır. Çevre kirliliği büyük bir endişe konusu ve dünya çapında ciddi bir sorun olarak kabul edilmektedir. Her geçen gün insan sağlığı, bitkiler ve hayvanlar üzerinde olumsuz etkilerini artırmaktadır. Bitkiler, özellikle ekosistemin yaşamsal bir parçası olup, biyotik ve abiyotik faktörlere oldukça duyarlıdır. Bitkilerde stres yaratan çevresel faktörler, bitkinin büyümesini ve gelişmesini büyük oranda etkilemektir. Sulara bulaşan kirleticiler toprağa ulaşmakta ve bitkiler tarafindan rahatlıkla alınabilmektedir (Garg ve Kaushik, 2005; Khalid vd., 2013). Evsel ve kentsel atıkların karışarak oluşturduğu su kirliliği, günümüzün en önemli küresel sorunlarından biridir. Yeteri kadar arıtılmayan kirlenmiş sular canlılar üzerinde besin zinciri yoluyla ciddi problemlere yol açabilmektedir. Özellikle yarı kurak bölgelerde etkisini daha fazla göstermektedir. Atıkların uzun süreli olarak sulara karışmasıyla birlikte, bitkilerde ve topraklarda metal kirlenmesi meydana gelebilmektedir (Singh vd., 2010; Chaoua vd., 2018) Sulama suyunun kalitesi, bitkilerin gelişimi ve verimliliği açısından oldukça önemlidir (Khan vd., 2013; Qureshi vd., 2016; Tran vd., 2017). Fizyolojik ve biyokimyasal bağlamda, serbest radikaller hücre metabolizmasının yan ürünleridir ve çeşitli antioksidan elementler ile denge sağlarlar. Kirleticiler, oksidatif süreci ortaya çıkaran oksidatif antioksidan dengeyi bozabilir (Isaksson, 2010; Duenas vd., 2014). $\mathrm{Bu}$ nedenle, antioksidan savunmanın tepki kapasitesi, organizmaların toksik kaynaklı oksidatif strese karşı korunmasında önemli bir rol oynamaktadır. Gerçekten de, 
hücrelerde yüksek bir antioksidan kapasitenin korunması, farklı çevresel stres türlerine karşı toleransı artırabilir (Koivula ve Eeva, 2010; Duenas vd., 2014).

Kirlenmeye bağlı oksidatif hasara karşı bu antioksidan kapasite tepkisi, kontaminasyonun potansiyel zararl1 etkisini izlemek için güvenilir bir araç olarak kullanılabilir (Isaksson, 2010; Duenas vd., 2014). Bitkiler, tuzluluk ve su stresi gibi çevresel streslere, hücresel metabolizmalarını değiştirerek ve çeşitli savunma mekanizmalarını aktive ederek tepki verir ve buna uyum sağlarlar. Savunma mekanizmaları içinde antioksidan enzimler süperoksit dismutaz (SOD), peroksidazlar (POD) ve katalaz (CAT) önemli yere sahiptir (Osma vd., 2017). Bugüne kadar farklı nitelikteki atı suların, sulamada kullanılmasıyla ilgili birçok çalışma yapılmıştır. Daha önce yapılmış çalışmalardan farklı olarak, klima atık suların arpa (H. vulgare L.) ve buğday ( $T$. aestivum L.)'ın gelişimleri üzerindeki etkisi araştırılmıştır.

\section{Materyal ve Metot}

Çalışma materyali olarak klima atık suyu ile birlikte, arpa ( $H$. vulgare) ve buğday ( $T$. aestivum L.) bitkileri kullanılmıştır. Buğday ve arpalara verilen klima atı suyu 1/5, 2/5 ve $3 / 5$ 'i olacak şekilde üç farklı oranda toprağa uygulanmıştır. Çalışmada, örnekler 3 tekerrür olarak yetiştirilerek, elektrolit sızıntı, MDA ve antioksidan enzim aktiviteleri belirlenmiştir. Buğdayların ekimi için her bir saksıya $650 \mathrm{~g}$ toprak konularak $7 \mathrm{~g}$ buğday ve $5 \mathrm{~g}$ arpa tohumu ekilip, tohumların üzeri $100 \mathrm{~g}$ toprak ile kaplanmıştır. Daha sonra tarla kapasitesi hesaplanarak, ilk gün $250 \mathrm{ml}$ sulama yapılmıştır. Sulama yapılırken kontrol grubu haricindeki gruplara verilen suya $1 / 5,2 / 5,3 / 5$ oranında yine klima suyu eklenmiştir. Belirli aralılarla klima suyundan aynı oranlarda olacak şekilde sulamalar tekrarlanmıştır. Buğdayın 15 gün, arpanın ise
11 günün sonunda hasadı yapılmıştır. Hasat sırasında yetişen buğday ve arpaların ağırlıkları belirlenmiştir. Daha sonra, fizyolojik ve biyokimyasal araştırmalar için yeteri kadar örnek ayrılmıştır. Yetiştirme işlemleri, bitkilerimizin ihtiyaç duyduğu sıcaklık isteği $5-10{ }^{0} \mathrm{C}$ ' ye, nem oranı isteği ise \% 60'a göre ayarlanarak laboratuvar ortamında gerçekleştirilmiştir. Buğday ve arpa çimlendikten sonra ortam sicaklığ 10 $15{ }^{0} \mathrm{C}$ olarak ayarlanmıştır (Osma vd., 2017).

\subsection{Elektrolit Sızıntı Miktarının Belirlenmesi}

10 tane deney tüpü saf sudan geçirildikten sonra, $0.1 \mathrm{~g}$ taze bitki yaprağı konuldu. $\mathrm{Bu}$ tüplerin içine $4 \mathrm{~mL}$ saf su eklenerek $4{ }^{\circ} \mathrm{C}$ 'de 24 saat bekletilmiştir. Bir günün sonunda tüplerdeki saf suya geçen iyon miktarı, elektriksel kondüktivimetre ile ölçülmüştür (Griffith vd., 1992; Osma vd., 2018).

\subsection{Lipid Peroksidasyon Aktivitesinin Belirlenmesi}

$0.5 \mathrm{~g}$ bitki yaprağı, $5 \mathrm{~mL} \% 5$ lik TCA (Trichloroacedic Acid) içerisinde homojenize edilmiştir. Homojenat 10.000 xg'de yaklaşık 15 dakika kadar santrifüj yapılmıştır. Tüpün süpernatant kısmından $4 \mathrm{~mL}$ alınarak üzerine $1 \mathrm{~mL} \% 0.5$ lik TBA çözeltisi eklenmiştir. Reaksiyon sonucunda oluşan karışım, kaynar suda 30 dakika inkübe edildi ve tüpler buz banyosuna alınarak reaksiyon durdurulmuştur. Örnekler birkez daha 10.000 xg'de 10 dakika santrifüj edilmiştir. Oluşan süpernatant k1smı spektrofotometrede 532 $\mathrm{nm}$ ve $600 \mathrm{~nm}$ de absorbans değeri belirlenmiştir. Lipid peroksidasyon değerinin hesaplanması için; 532 nm'de ölçülen absorbans değerinden $600 \mathrm{~nm}$ 'de belirlenen değeri çıkarılarak ve $1 \mathrm{~mL}$ çözeltideki MDA (nmol/ml) hesaplanmıştır (Ananieva vd., 2002; Osma vd., 2014). 


\subsection{Katalaz Enzim Aktivitesinin Belirlenmesi}

Katalaz enzim aktivitesi, (Havir ve Mchale, 1987)'nin dayandırılarak uygulanan yöntem ile belirlenmiştir. $\mathrm{Bu}$ absorbans azalma değeri $240 \quad \mathrm{~nm}$ 'de spektrofotometrede ölçülerek hesaplanmıştır. $0.5 \mathrm{~g}$ yaprak örneği toz haline getirilerek $5 \mathrm{~mL}$ ekstraksiyon tamponunda (1 mM EDTA (0.04 gr), \%1 PVP ve $5 \mathrm{ml} 100 \mathrm{mM}$ potasyum fosfat tamponunda ( $\mathrm{pH}$ 7.0) homojenize edilmiştir. Homojenat $+4^{0}$ 'de 14.000 rpm ile 20 dakika santrifüj yapılmıştır. Sonrasında, $5 \mathrm{mM} \mathrm{H}_{2} \mathrm{O}_{2}$ çözeltisinden $3 \mathrm{~mL}$ 'lik spektrofotometre tüpüne sirasiyla; $0.15,0.3,0.45,0.6,0.75$, $0.9,1.05,1.2,1.35$ ve $1.5 \mathrm{~mL}$ konulmuştur. Saf su ile tüpün hacmi $1.5 \mathrm{~mL}$ ' ye tamamlanarak ve her tüpe $1.47 \mathrm{~mL}, 103,5$ $\mathrm{mM} \quad \mathrm{KH}_{2} \mathrm{PO}_{4} \quad$ hazirlanan substrat tamponundan $\left(100 \mathrm{~mL}\right.$ için; $1.4 \mathrm{~g} \mathrm{KH}_{2} \mathrm{PO}_{4}$, $80 \mathrm{~mL}$ saf suda çözülerek $1 \mathrm{~N} \mathrm{NaOH}$ ile $\mathrm{pH}$ 7.5'a kadar titre edilerek, son hacim 100 $\mathrm{mL}$ 'ye tamamlanmıştır) olacak şekilde $30 \mu \mathrm{L}$ de su ilave edilmiştir. Son olarak, küvet spektrofotometreye konularak $240 \mathrm{~nm}$ 'de absorbans azalışı, 3 dakika boyunca 15 saniye periyotlarla köre karş1 okunmuştur (Osma vd., 2017).

\subsection{Süperoksit Dismutaz Aktivitesinin Belirlenmesi}

Süperoksit dismutaz (SOD) aktivitesi, nitro blue tetrazoliumun (NBT) fotokimyasal indirgenmesine bağlı inhibisyonunun, spektrofotometrik olarak belirlenme esasina dayanmaktadır (Agarwal ve Pandey 2004). Reaksiyon karışımını (3 mL); $50 \mathrm{mM}$ $\mathrm{KH}_{2} \mathrm{PO}_{4}$ (pH: 7.8), $13 \mathrm{mM}$ metiyonin, $75 \mathrm{M}$ NBT, 2 M riboflavin ve $0.1 \mathrm{mM}$ EDTA oluşturmaktadır. (SOD) enzim aktivitesinin ölçümünü yapabilmek için $3 \mathrm{~mL}$ spektrofotometre küvetine yukarıda belirtilen riboflavin içermeyen reaksiyon karışımdan $2.84 \mathrm{~mL}$ alını üzerine $100 \mu \mathrm{L}$ enzim ekstraktı eklenmiş̧tir. Reaksiyon, tüp üzerine 100 M'lık riboflavin çözeltisinden $60 \mathrm{~mL}$ pipetlenip birbirine karıştırıldıktan hemen sonra, beyaz bir 1şık kaynağına maruz bırakılmak suretiyle başlatılmıştır. Hazırlan tüp, 1şık kaynağında $15 \mathrm{dk}$. bekletilip oluşan reaksiyon 1 şı kaynağının kapatılmasıyla durdurulmuştur. $15 \mathrm{dk}$. boyunca NBT'nin renk açılma yoğunluğu 560 nm'de köre karş1 okunmuştur. Kör, aynı işlemin enzimsiz şeklidir. SOD aktivitesinin 1 ünitesi, 560 nm'de gözlenen NBT indirgenmesinin \% 50 inhibisyonuna sebep olan enzim konsantrasyonu, 1 enzim ünitesi olarak kabul edilerek, elde edilen veriler EU/g doku olarak tespit edilmiştir (Osma vd., 2017).

\subsection{Element Analizi}

Buğdaylarda 15, arpalarda 11. günün sonunda, hasat işlemi yapılarak örnekler etüvde $80^{\circ} \mathrm{C}$ 'de 24 saat kurutulmuştur. Daha sonra havanda dövülerek toz haline getirilmiştir. Her örnekten sonra havan etil alkol ile y1kanarak kontaminasyonun engellenmesi sağlanmış olup, toz haline getirilmiş örnekler ayrı poşetlere konulup isimlendirilerek saklanmıştır. Bitki örneklerinden $\quad 0,5$ gr tartılarak teflon hücrelere konulmuştur. Daha sonra, mikrodalga firınında örneklere $10 \mathrm{~mL} \%$ 65'lik $\mathrm{HNO}_{3}$ eklendikten sonra Nowave SA (Kanada) mikrodalga cihazında 280 PSI basinçta ve $180{ }^{\circ} \mathrm{C}$ 'de 20 dakika boyunca yakılmıștır. Hücreler mikrodalgadan çıkarıldıktan sonra soğutulmuştur. Hücreler içerisindeki numuneler, deiyonize su ile 50 mL'ye tamamlanmıştır. Filtre kağıdı ile süzüldükten sonra Spectro blue marka ICPOES cihazında uygun dalga boylarında okunması gerçekleştirilmiştir (Osma vd., 2014).

\section{6. İstatistiksel Analizler}

Elde edilen veriler, \%95 güven aralığında istatistiksel olarak karşılaştırılmışıtır (Elveren vd., 2015).

\section{Bulgular}

Yapılan çalışmada klima atık suyunun farklı konsantrasyonlarında buğday (T. aestivum) ve $\operatorname{arpa}(H . \quad$ vulgare $)$ üzerinde etkileri 
incelendi. Çalışmada hasat sonrası bitki ağırlıkları, SOD, CAT enzim aktiviteleri ile birlikte elektrolit sızıntı, MDA miktarları tespit edilerek, önemli sonuçlara ulaşılmıştır. Elde edilen verilere göre, bitkinin strese girdiğinin bir göstergesi olarak, kontrol grubu örnekleri ile klima atık sularının uygulandığı örnekler kiyaslandığında hasat sonrası bitki ağırlıkları hariç elektrolit sızıntı, MDA, antioksidan enzim aktivitelerinde ciddi oranda bir artışın olduğu gözlenmiştir. Özellikle klima atık sularının konsantrasyonu arttıkça çalışılan parametrelerin de paralel olarak arttığı görülmüştür. Hasat sonrası örnekler tartılmış olup, kontrol örneklerinin klima atık sularının kullanıldığı örneklere göre daha ağır olduğu tespit edilmiştir (Şekil 1). Elektrolit sızıntı ölçümlerine göre buğdayda $292.85-343.75 \mu \mathrm{s.cm}{ }^{-1}$ arasında değerler alırken arpada ise $59-77 \mu \mathrm{s} . \mathrm{cm}^{-1}$ değerlere sahip olduğu görülmüştür. Buğdayda, en yüksek değer 3/5 oranında, su ile karıştırılan klima atık suyunun kullanıldığı örneklerde tespit edilmiştir (Şekil 2). MDA konsantrasyonunun buğdayda 11.35-16.1 nmol.g $\mathrm{g}^{-1}$ arasında iken arpada 2.33-4.07 nmol. $\mathrm{g}^{-1}$ değerlerine sahip olduğu görülmektedir. Kontrol örnekleri ile diğer uygulama örnekleri arasında anlamlı farklıklar olduğu tespit edilmiştir (Şekil 3). CAT aktivitesi incelendiğinde, konsantrasyon artışı ile birlikte CAT enzim aktivitesinde de artış olduğu görülmektedir. CAT enzim aktivite değerlerinin buğdayda
4453.3-5102.2 EU g ${ }^{-1} \mathrm{FW}$ arasinda, arpada ise 2063-3084 $\mathrm{EU} \quad \mathrm{g}^{-1} \quad \mathrm{FW}$ değiştiği belirlenmiştir. Klima atık su konsantrasyonu arttıkça, buğday örneklerinde CAT aktivitesinin ciddi oranda artış olduğu tespit edilmiştir (Şekil 4). SOD enzim aktivitesinde ise, eklenen klima atı sularının konsantrasyonuna bağlı olarak artış olduğu gözlenmiştir. SOD enzim aktivite değerleri buğdayda $494.00-617.47 \quad$ EU g ${ }^{-1} \quad F W$ değerleri arasında olup, arpada 174.6-245.0 EU g ${ }^{-1} \mathrm{FW}$ olarak belirlenmiştir. SOD enzim aktivitesi için kontrol grubu örnekleri ile diğer uygulama örnekleri arasında güçlü yönde anlamlı farklıkların olduğu belirlenmiştir. Klima atık sularının kullanıldığı örneklerde, kontrol grubu örneklerine göre MDA miktarında önemli oranda artış belirlenmiştir (Şekil 3).

$\mathrm{Bu}$ çalışmada element analizler de yapılmış olup, önemli sonuçlar elde edilmiştir. Genel olarak element verileri incelendiğinde klima atık suların kullanıldığı bitki örneklerinde element konsantrasyonlarında farkl1lıklar görülmüştür (Tablo 1).

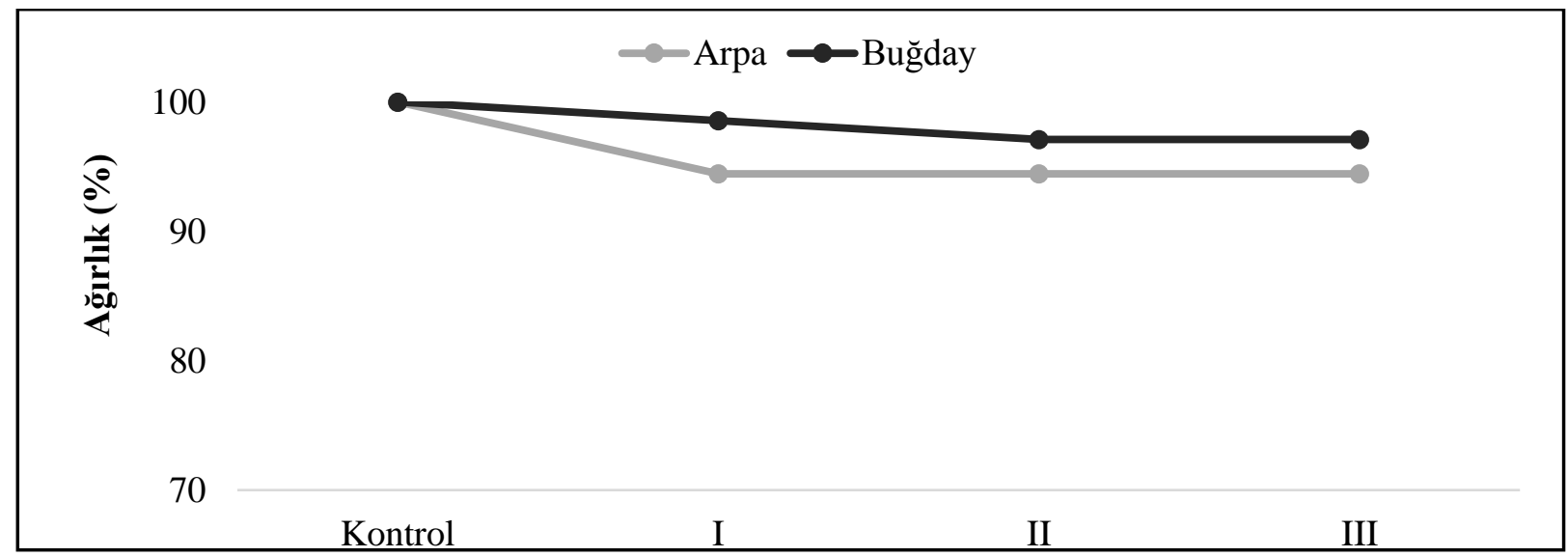

Şekil 1. Hasat sonrası T. aestivum ve H. vulgare'nin yaş ağırlıkları (Kontrol, I = 1/5 klima suyu, II= 2/5 klima suyu, III = 3/5 klima atık suyu) 


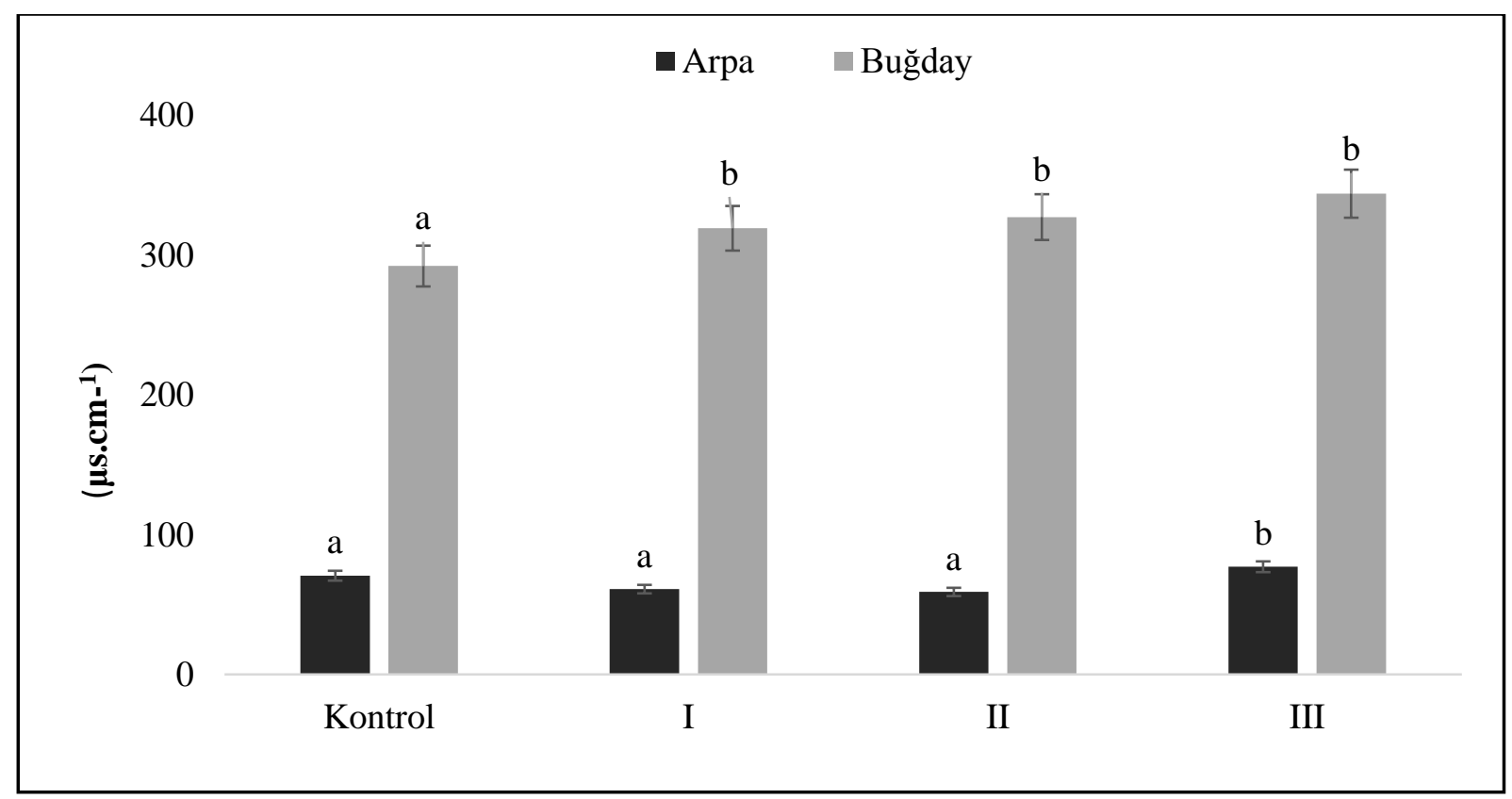

Şekil 2. Buğday (T. aestivum) ve arpaya (H. vulgare) farklı konsantrasyonlarda uygulanan klima atık suyunun Elektrolit Sızıntı üzerinde etkisi (Kontrol, I = 1/5 klima suyu, II= 2/5 klima suyu, III = 3/5 klima atık suyu) (a, b ve c istatistiksel olarak farklılı̆̆ göstermektedir)

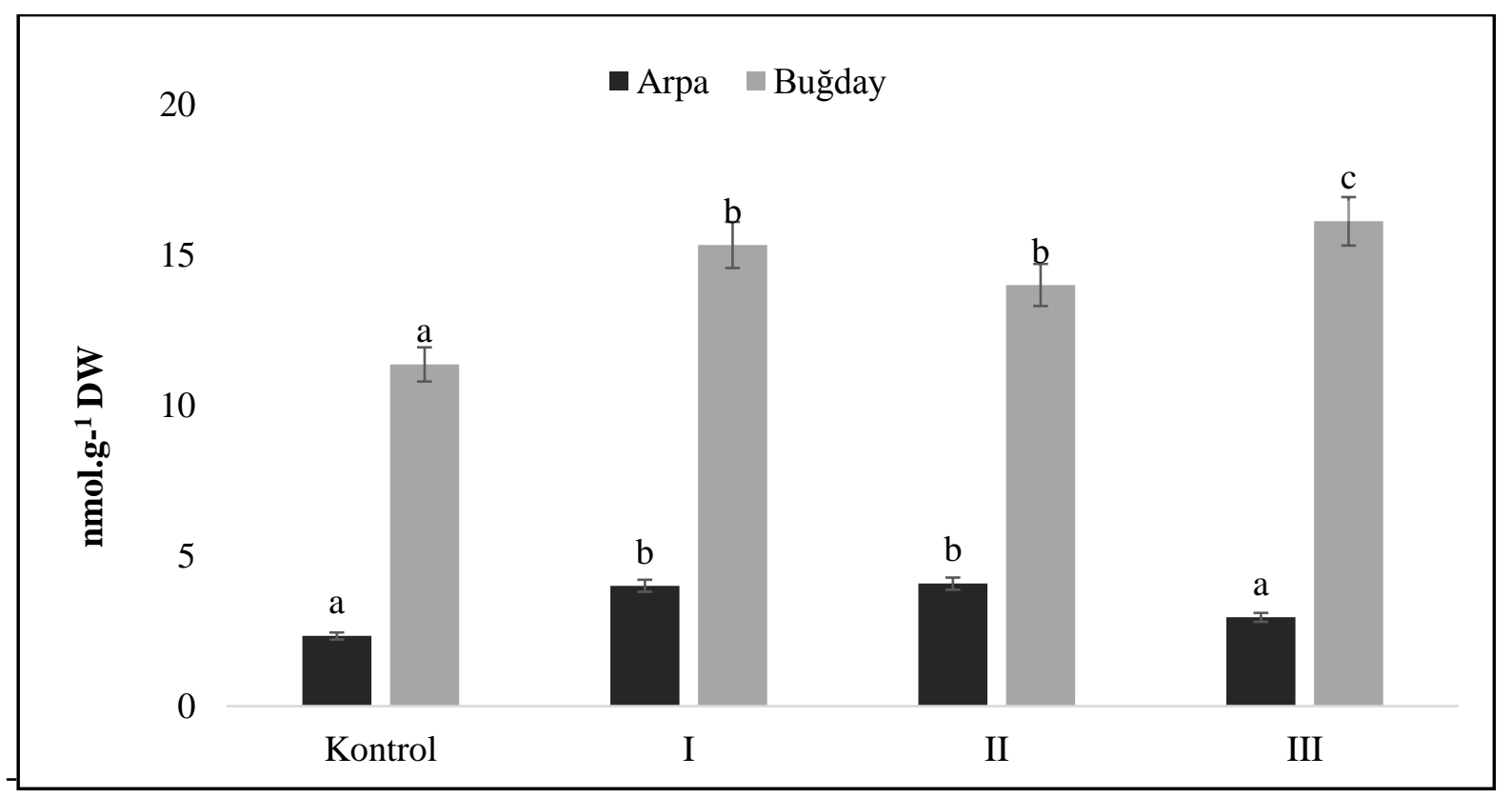

Şekil 3. Buğday (T. aestivum) ve arpaya (H. vulgare) farklı konsantrasyonlarda uygulanan klima atık suyunun MDA üzerinde etkisi (Kontrol, $\mathrm{I}=1 / 5 \mathrm{klima}$ suyu, II $=2 / 5 \mathrm{klima}$ suyu, III $=3 / 5 \mathrm{klima}$ atı suyu $(\mathrm{a}, \mathrm{b}$ ve $\mathrm{c}$ istatistiksel olarak farklılı̆ğ göstermektedir) 
6000

$$
\text { - Arpa Buğday }
$$

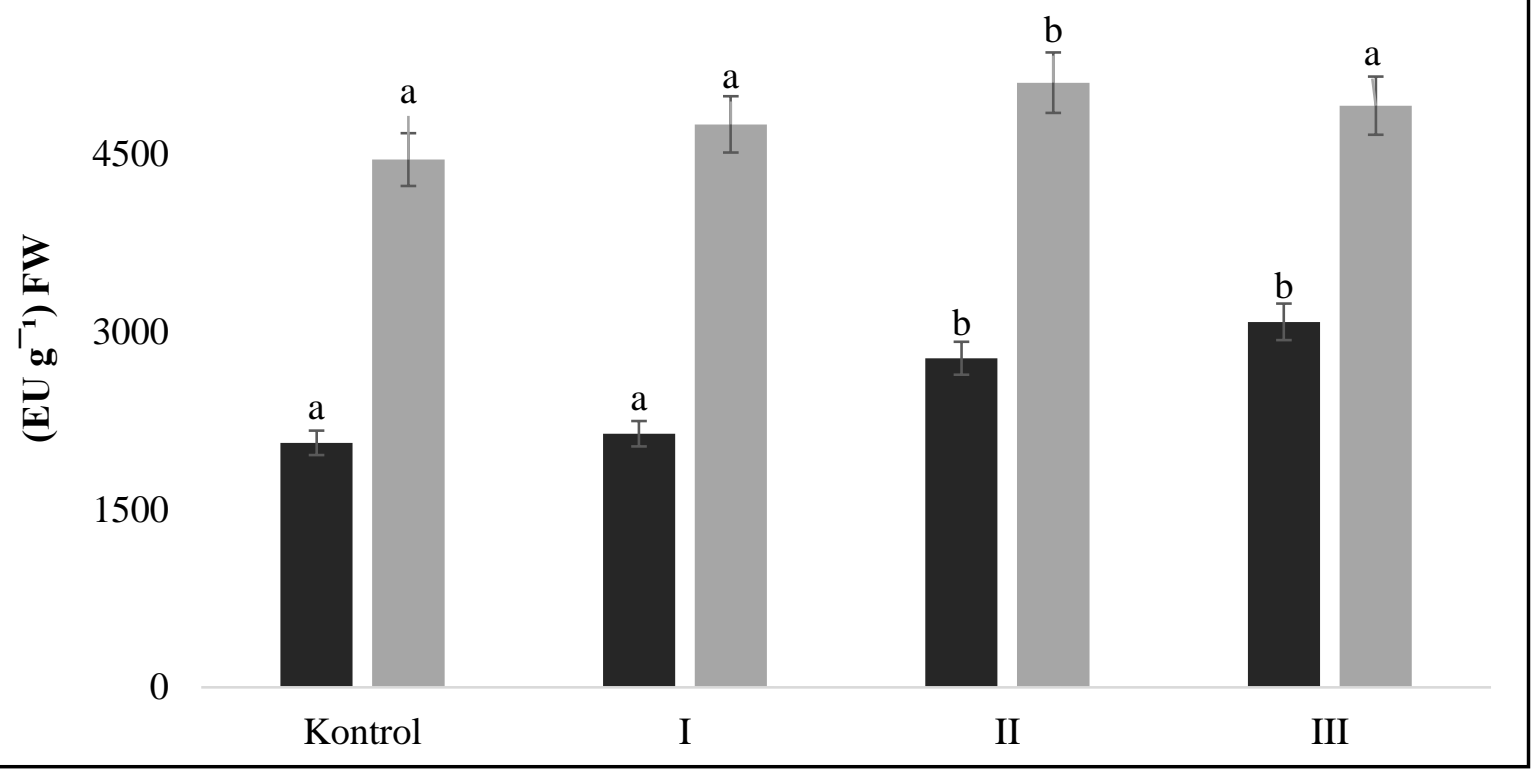

Şekil 4. Buğday (T. aestivum) ve arpaya (H. vulgare) farklı konsantrasyonlarda uygulanan klima atık suyunun CAT enzim aktivitesine etkisi (Kontrol, $\mathrm{I}=1 / 5 \mathrm{klima}$ suyu, II=2/5 klima suyu, III = 3/5 klima atık suyu) (a ve b istatistiksel olarak farklılı̆̆ göstermektedir)

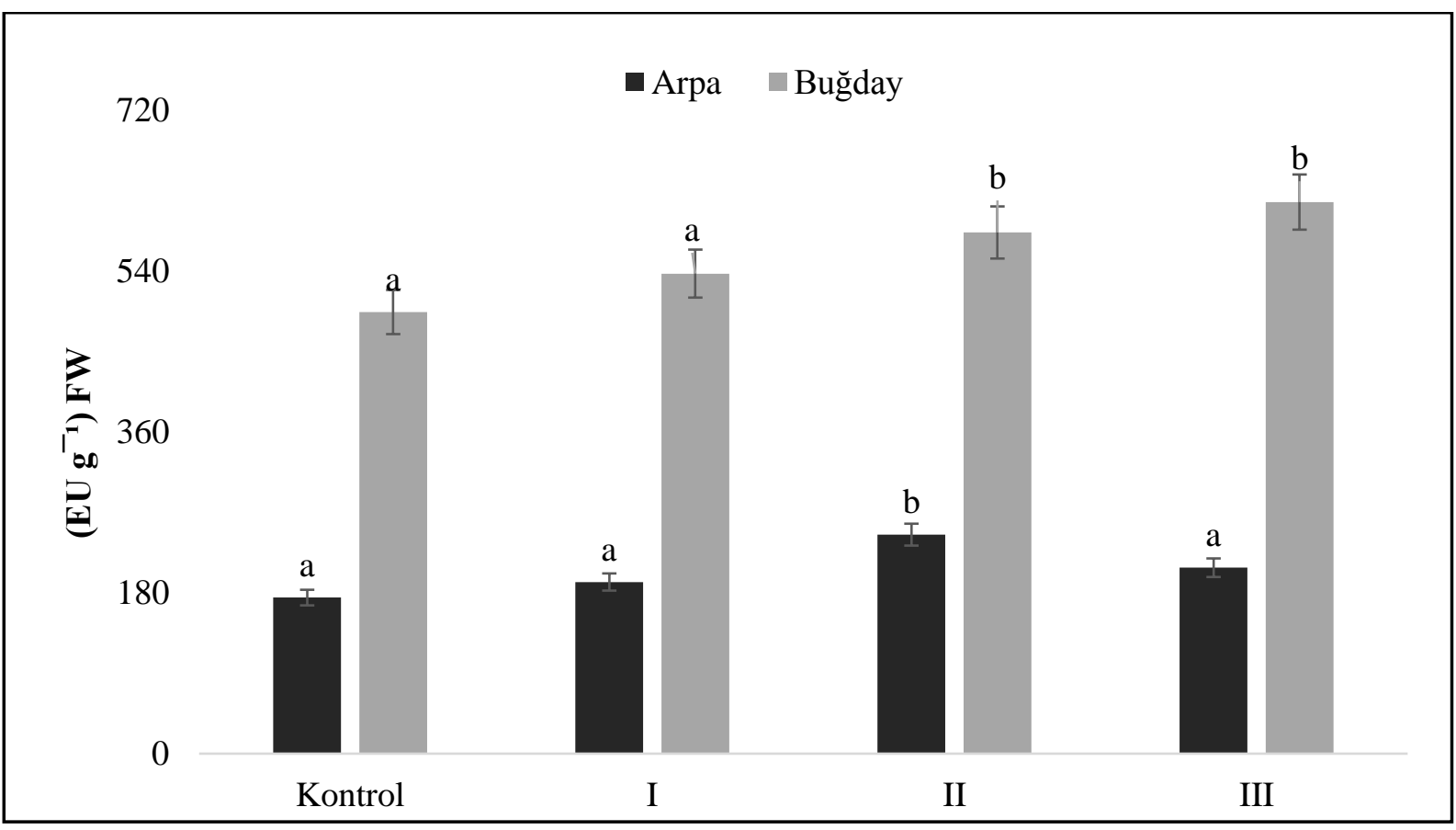

Şekil 5. Buğday (T. aestivum) ve arpaya (H. vulgare) farklı konsantrasyonlarda uygulanan klima atık suyunun SOD enzim aktivitesine etkisi (Kontrol, I = 1/5 klima suyu, II=2/5 klima suyu, III = 3/5 klima atık suyu) (a ve b istatistiksel olarak farklılı̆̆ göstermektedir) 
Tablo 1. Klima atık suyunun farklı konsantrasyonlarına bağlı olarak buğday ve arpada bazı element miktarları $(\mu \mathrm{g} / \mathrm{g} \mathrm{dw})$

\section{Buğday}

\section{Arpa}

\begin{tabular}{ccccc|cccc} 
Element & Kontrol & I & II & III & Kontrol & I & II & III \\
\hline $\mathbf{C a}$ & 1256.2 & 1319.4 & 1224.3 & 1282.1 & 1738.4 & 1776.8 & 1666.7 & 1100.4 \\
$\mathbf{M g}$ & 2602.1 & 2453.2 & 2304.1 & 2312.2 & 3346.9 & 3213.3 & 6147.7 & 2742.8 \\
$\mathbf{K}$ & 61100 & 58301.9 & 58052.1 & 54946.9 & 56466 & 57912 & 35048.9 & 32249.3 \\
$\mathbf{C u}$ & 15.3 & 11.7 & 12.1 & 12.6 & 16.8 & 13.4 & 13.5 & 14.4 \\
$\mathbf{A l}$ & 4.9 & 21.5 & 15.5 & 11.4 & 11.6 & 123.1 & 58.7 & 21.8 \\
$\mathbf{C r}$ & 0.5 & 0.48 & 0.47 & 2.9 & 0.65 & 12.3 & 3.4 & 0.7 \\
$\mathbf{C d}$ & 0.04 & 0.008 & 0.04 & 0.15 & 0.04 & 0.04 & 0.033 & 0.03 \\
\hline
\end{tabular}

\section{Sonuç ve Tartışma}

Klima atık sularının kullanıldığı bu çalışmada kısa süreçte laboratuar ortamında yetiştirilen arpa ve buğdaylarda farkliklar olduğu görülmüş olup, yukarıda yapılan çalışmalar ile karşılaştırıldığında verilerin anlamlı olduğu sonucuna ulaşılmıştır. Kentsel ve evsel atıkların karıştığı sulama sularının bitkiler üzerindeki etkilerine yönelik birçok çalışma yapılmıştır. Özellikle bitkilerde ağır metal birikimi ve ağır metallerin bitkiler üzerindeki etkileri incelenmiştir. $\mathrm{Bu}$ çalışmalar incelendiğinde; Weihong vd. (2009) yaptıkları çalışmada buğdaygillerden olan Vetiveria zizanioides $\mathrm{L}$. Nash kök ve filizlerinin $\mathrm{Zn}$ ve Cd alımlarını araştırmışlardır. $\mathrm{Bu}$ metallerin bitki biomasını düşürdüğü, MDA ve antioksidan enzim sistemlerini aktive ettiğini ve özellikle $\mathrm{Cd}$ ile $\mathrm{Zn}$ beraber verildiğinde aktivitenin daha fazla arttığını belirlemişlerdir. Abegunrin vd. (2016) banyo ve mezbaha atık suları ile sulanmış patlıcan ve ıspanak yetiştiriciliği üzerine bir çalışma yapmışlardır. Sonuçta atıkların karışmış olduğu sular ile yetiştirilen örneklerde farklılıklar olduğunu gözlemlemişlerdir. Sonuçta atık sulara karışan atık maddelere göre, yetiştirilen ürünlerde büyüme ve verimliliğin değişebileceğini ortaya koymuşlardır. Khalid vd. (2013) yaptığ 1 çalışmada işlenmiş atıksular ile işlenmemiş atık sular arasındaki farkı incelemiş ve bezelye bitkisinde işlenmiş suların daha etkili olduğunu ortaya koymuşlardır. Al-Othman vd. (2016) farklı su kaynaklarını buğday sulamada kullanmışlar ve buğdaylarda ağır metal birikiminde farklıklar olduğunu tespit etmişlerdir. Meng vd. (2016) uzun süreli kanalizasyon sularını kullanarak yaptıkları çalışmada ağır metal birikiminin sebzelerde daha fazla olduğunu belirlemişlerdir. Raja vd. (2015) yaptıkları çalışmada atık sular ile sulamış oldukları sebzelerde, özellikle yapraklı sebzelerde ağır metal birikiminin daha fazla olduğunu tespit etmişlerdir. Ma vd. (2015) yaptıkları bir çalışmada, kömür madencilik faaliyetleri sonucu ortaya çıkan atık sular ile sulanmış topraklarda değişimler olduğu tespit etmişlerdir. Bununla birlikte, bu atık suların buğdaylarda da verimliliğin düşmesine ve bitki bünyesinde ağır metal birikiminin artış göstermesine neden olduğunu gözlemlemişlerdir. Balkhair ve Ashraf (2016) Suudi Arabistan'nın bat1 kesimlerinde kanalizasyon suları ile sulanmış bamyalarda ağır metal birikiminin arttığını 
belirlemişlerdir. Klimaların avantajlarının yanında dezavantajları da olabilmektedir. $\mathrm{Bu}$ dezavantajları gidermek için bazı önlemler alınmalıdır. Ayrıca, küresel ısınma ve çevresel etkileri açısından, çevre dostu klimalar seçilmeli ve mümkün olduğunca yeni klima teknikleri geliştirilmelidir. Tarımsal alanda su kullanımı, topraklar, yeraltı suları ve yüzey sularının ciddi derecede kirlenmesine neden olmaktadır. $\mathrm{Bu}$ suların kirlenmesine neden olan kirletici unsurlar sediment, bitki besin maddeleri, eriyen ve erimeyen tuzlar, tarımda kullanılan ilaçlar, toksik iz elementler ve patojenler olarak sıralanabilir. Bazen, sulama sularına organik maddelerin karışması sonucunda bu suların, yetiştirilen ürünlerde verimliliği artırmasına karşın, sulama suyu ile birlikte taşınan kimyasal madde, gübre ve pestisitler büyük oranlarda kirlilik tehdidi oluşturabilmektedir. Dolaysıyla sulama sularına karışan maddelerin içeriğine dikkat edilmeli ve buna yönelik önlemler alınmalıdır. Sonuç olarak, yapılan çalışmada klima atık sularının sulama sularına karışmasına bağlı olarak yetiştirilecek ürünlerin verimliliğinde azalma ile birlikte, toksik maddelerin birikimine de yol açabileceği kanısına ulaşılmıştır.

\section{Kaynaklar}

Abegunrin, T.P., Awe, G.O., Idowua, D.O., Adejumobi, M.A. 2016. Impact Of Wastewater İrrigation On Soil PhysicoChemical Properties, Growth And Water Use Pattern of Two İndigenous Vegetables İn Southwest Nigeria. Catena, 139, 167-178.

Agarval, S. and Pandey V. 2004. Antioxidant Enzyme Responses To Nacl Stress in Cassia Angustifolia. Biologia Plantarum, 48(4): 555-560.

Ananieva, E.A., Alexieva, V.S., Popova, L.P. 2002. Treatment With Salicylic Acid Decreases The Effects of Paraquat on Photosynthesis. Journal of Plant Physiology, 159, 685-693.
Albayrak, T., Mor, F., 2011. Comparative Tissue Distribution of Heavy Metals in Housesparrow (Passer Domesticus Aves) in Polluted And Reference Sites in Turkey. Bulletin Environmental Contamination Toxicology, 87, 457462.

Al-Othman, Z.A. Ali, R., Al-Othman, A.M., Ali, J.,. Habila, M.A. 2016. Assessment of Toxic Metals in Wheat Crops Grown On Selected Soils, İrrigated By Different Water Sources. Arabian Journal of Chemistry, 9, 1555-1562.

Balkhair, K.S., Ashraf, M.A. 2016. Field Accumulation Risks of Heavy Metals in Soil And Vegetable Crop İrrigated With Sewage Water in Western Region Of Saudi Arabia. Saudi Journal of Biological Sciences, 23, 32-44.

Chaoua, S., Boussaa, S., Gharmali, A.E., Boumezzough, A. 2018. Impact of İrigation With Wastewater on Accumulation of Heavy Metals in Soil and Crops in The Region of Marrakech in Morocco. Journal of the Saudi Society of Agricultural Sciences, https://doi.org/10.1016/j.jssas.2018.02. 003.

Chen, F., Ying, G.G., Kong, L.X., Wang, L., Zhao, J.L., Zhou, L.J., Zhang, L.J. 2011. Distribution and Accumulation of Endocrine-Disrupting Chemicals and Pharmaceuticals in Wastewater İrrigated Soils in Hebei, China. Environmental Pollution, 159, 14901498.

Duenas, A.H., Pineda, J., Antonio, M.T., Aguirre, J.I. 2014. Oxidative Stress of House Sparrow As Bioindicator of Urban Pollution. Ecological Indicators, 42, 6-9.

Elveren, M., Osma, E., Karakoyun, G. 2015. Erzincan'nın Farklı Bölgelerindeki Sarıçamların (Pinus sylvestris L. var. Hamata Steven) Ağaç Bileşenleri ve Yetiştikleri Topraklarda Mineral Elementlerin Birikimi, Celal Bayar Üniversitesi Fen Bilimleri Dergisi, 11(2), 119-126.

Garg, V.K., Kaushik, P. 2005. Influence of Textile Mill Waste Water İrrigation on 
Growth of Sorghum Cultivars. Applied Ecology and Environmental Research, 6, 1-12.

Graudenz, G.S., Oliveira, C.H., Tribess, A., et.al. 2005. Association of AirConditioning With Respiratory Symptoms in Office Workers in Tropical Climate. Indoor Air, 15, 6266.

Griffith, M., Ala P., Yang D.S.C., Hon W.C., Moffatt B.A. 1992. Antifreeze Protein Produced Endogenously in Winter Rye Leaves. Plant Physiology, 100, 593596.

Havir, E.A., Mchale, N.A. 1987. Biochemical and developmental characterization of mutiple forms of catalase in tobacco leaves. Journal of Plant Physiology, 84, 1291-1294.

Isaksson, C. 2010. Pollution and İts İmpact on Wild Animals: A Meta-Analysis Onoxidative Stres. EcoHealth, 7, 342350 .

Khalid, A., Saba, B., Kanwal, H., Nazir, A., Arshad, M. 2013. Responses of Pea and Wheat to Textile Wastewater Reclaimed by Suspended Sequencing Batch Bioreactors. International Biodeterioration \& Biodegradation, 85, 550-555.

Khan, M.U., Malik, R.N., Muhammad, S. 2013. Human Health Risk From Heavy Metal Via Food Crops Consumption With Wastewater İrrigation Practices İn Pakistan. Chemosphere, 93, 22302238

Koivula, M.J., Eeva, T. 2010. Metal-Related Oxidative Stress in Birds. Environmental Pollution, 158, 23592370.

Ma, S.C., Zhang, H.B., Mab, S.T., Wang, R., Wang, G.X., Shao, Y., XiLi, C. 2015. Effects of Mine Wastewater İrigation on Activities of Soil Enzymes and Physiological Properties, Heavy Metal Uptake And Grain Yield in Winter Wheat. Ecotoxicology and Environmental Safety, 113, 483-490.

Meng, W., Wang, Z., Hu, B., Wang, Z., Lic, H., Goodman, R.C. 2016. Heavy
Metals in Soil and Plants After LongTerm Sewage İrrigation at Tianjin China: A Case Study Assessment. Agricultural Water Management, 171, 153-161.

Osma E., İlhan V., Yalçın İ.E. 2014. Heavy metals accumulation causes toxicological effects in aquatic Typha domingensis Pers. Brazilian Journal of Botany, 37(4),461-467.

Osma, E., Elveren, M., Türkoğlu, E., Yavuzer, H., Çı̆̆ır, Y. 2017. Tıbbi İlaçlar ve Kişisel Bakım Ürünlerinin (PPCPs) Triticum aestivum L. Üzerinde Antioksidan Enzim Aktivitelerine Etkileri. Süleyman Demirel Üniversitesi Fen Bilimleri Enstitüsü Dergisi, 21(2), 535-541.

Osma E., Cigir Y., Karnjanapiboonwong A., Anderson T.A. 2018. Evaluation of selected pharmaceuticals on plant stress markers in wheat. International Journal of Environmental Research, 12(2), 179188.

Özçimen, D., Terzioğlu, P., Yücel, S. 2012. Human Health Effects of Air Conditioners. Journal of Engineering and Natural Sciences, Sigma 30, 56-65.

Pan, M., Chu, L.M. 2017. Transfer of Antibiotics From Wastewater or Animal Manure to Soil and Edible Crops. Environmental Pollution, 231, 829-836.

Qureshi, A.S., Hussain, M.I., Shoaib, İ.,Khan, Q.M. 2016. Evaluating Heavy Metal Accumulation and Potential Health Risks in Vegetables İrigated With Treated Wastewater. Chemosphere, 163, 54-61.

Raja, S., Masoom, H., Cheema, N., Babarb, S., Khana, A.A, Murtazac, G., Aslama, U. 2015. Socio-Economic Background of Wastewater İrigation and Bioaccumulation of Heavy Metals in Crops and Vegetables. Agricultural Water Management, 158, 26-34.

Righi, E., Aggazzotti, G., Fantuzzi, G., vd. 2002. Air Quality and Well-Being Perception in Subjects Attending University Libraries in Modena (Italy). 
The Science of the Total Environment, 286, 41-50.

Singh, A., Sharma, R.K., Agrawal, M., Marshall, F.M. 2010. Risk Assessment of Heavy Metal Toxicity Through Contaminated Vegetables From Waste Water İrigated Area of Varanasi, India. International Society Tropical Ecology, 51, 375-387.

Söğüt, M.Z., Karakoç, H. 2013. Klimalarda Enerji Verimliliği Sınıflandırılmasında Farklı Bir Yaklaşım: Ekserjetik Verimlilik Oranı ve Çevresel Etki Oran1. 11. Ulusal Tesisat Mühendisliği Kongresi, 859-871.

Stagoll, K., Manning, A.D., Knight, E., Fischer, J., Lindenmayer, D.B. 2010. Using Bird-Habitat Relationships to İnform Urban Planning. Landscape and Urban Planning, 98,13-25.

Tıraş, H.H. 2012. Sürdürülebilir Kalkınma ve Çevre: Teorik Bir İnceleme. Kahramanmaraş Sütçü İmam Üniversitesi, İktisadi ve İdari Bilimler Fakültesi Dergisi, Sayı: 2, 57-73.

Tran, T.K., Chiu, K.F., Lin, C.Y., Leu, H.J. 2017. Electrochemical Treatment of Wastewater: Selectivity of The Heavy Metals Removal Process. International Journal of Hydrogen Energy 42, 27741-27748.

Yan, C.X., Yang, Y., Zhou, J.L., Liu, M., Nie, M.H., Shi, H., Gu, L.J. 2013. Antibiotics in The Surface Water of The Yangtze Estuary: Occurrence, Distribution And Risk Assessment. Environmental Pollution., 175, 22-29.

Weihong, X.U., Wenyi, L.I., Jianping, H.E., Singh, B., Zhiting, X. 2009. Effects of İnsoluble $\mathrm{Zn}, \mathrm{Cd}$, And EDTA on The Growth, Activities of Antioxidant Enzymes And Uptake of $\mathrm{Zn}$ And Cd in Vetiveria zizanioides. Journal of Environmental Sciences, 21, 186-192. 